\title{
Anonymous Unemployed 2.0: The Needs of Forgotten Italian Workers
}

\author{
Concetta Papapicco, Isabella Quatera \\ University of Bari, Bari, Italy \\ Email: concetta.papapicco@uniba.it, isabella.quatera@uniba.it
}

How to cite this paper: Papapicco, C. and Quatera, I. (2018) Anonymous Unemployed 2.0: The Needs of Forgotten Italian Workers. Open Access Library Journal, 5: e4978. https://doi.org/10.4236/oalib.1104978

Received: October 10, 2018

Accepted: October 29, 2018

Published: November 1, 2018

Copyright ( 2018 by authors and Open Access Library Inc.

This work is licensed under the Creative Commons Attribution International License (CC BY 4.0).

http://creativecommons.org/licenses/by/4.0/

(c) (i) Open Access

\begin{abstract}
The unemployment rate of economically developed countries up to a few years ago is increasing and there are many intervention projects to manage this increase. Despite this, more and more human resources belong to the Job-less generation, including workers in protected categories, young people and workers forced to retrain, who fall into a spiral of silence, from which they can hardly get out, becoming "invisible". For this reason, the research aims to introduce a new perspective regarding listening to marginalized workers, observing them in natural contexts where it is easier to express their opinions. To date, the digital revolution and the organization of users on the Net, has allowed the creation of virtual groups that have become real movements of revolt or self-support. The study aims to investigate, through the virtual narratives of invisible workers, what are the real needs of a Job-less Human Resources in the current working situation and how it is possible to intervene to manage this emergency, starting from the assumption that it is necessary to promote a dialogue between workers and companies. The perspective used is the diatextual analysis, thanks to which the virtual experiences of 2.0 workers are considered in the light of the dense interweaving of text and context of enunciation. The methodology used is qualitative: a critical analysis of the discourse is applied, where the socio-epistemic rhetoric is highlighted, and it has been useful for understanding the requirements and needs of workers in the era of professional flexibility, on which they can take an intervention based on the person as a human resource, in order to face unemployment and not to forget them.
\end{abstract}

\section{Subject Areas}

Philosophy

\section{Keywords}

Job-Less Generation, Qualitative Methods, Narration of Needs 


\section{Liquid Work: Introduction to the New Career Perspectives}

Globalization, the crisis of social and political systems and the technological revolution have led to radical changes in the labor market. The opening of the borders and the breaking down of space-time barriers has led companies to carve out market niches in which to invest to be competitive, this has brought about a number of phenomena, ranging from offshore, outsourcing to intelligent working forms (smart working), following the Fourth Industrial Revolution. This panorama also has important repercussions on individual workers who, in most cases, are excluded from the labor market, since the resource requires flexibility, dynamism, with the possibility of vertical and horizontal transitions. Career developments also turn into this context: in fact, there is a transition from a more traditional career to a versatile and borderless career. The versatile career ("protean career") was defined by Hall and Mirvis [1] (1994) as subjective career goals through vocational behavior; the construct, instead, of career without boundaries ("boundaryless") has been defined by Arthur [2] [3] (1996) as the set of subjective and objective career dimensions on different levels of analysis, which include organizational positions, mobility, flexibility, work, opportunities and at the same time emphasize the link between organizational promotions and career paths. It was in 2003 that the sociologist Zygmunt Bauman introduced the concept of "liquidity" by attributing it to society, but which can also extend to the work context, in which it becomes difficult to imagine a future due to uncertainties, doubts and precariousness. This precariousness radiates more in marginalized areas of Europe, which are incapable of managing this emergency at political and economic level, which becomes the focus of many political and scientific debates. It is necessary not to marginalize the workers, but to occupy them, re-launching the social dialogue: where by dialogue we mean listening to marginalized workers to understand what their needs are in order to make them more competent and responsible for their careers. While globalization aimed at creating a "unitary village", on the other hand, it created a discrepancy between poor and rich countries with a weakening of national and cultural identity. This has repercussions on particular population targets, especially where there is a marginalization of the global system; increasing, as in the case of Italy, the rate of poverty and unemployment and giving rise to "Jobless" generations.

\section{Job Less Generation: The Bionomy between Poverty and Social Exclusion}

In this globalized and flexible world, in which even the professional identities become more and more "Glocal" identities, that is able to tell and generate meaning by talking about the Self and the professional reality in which they are immersed or would like to be part, there is a portion of human resources that are cut off from the world of work and for this reason they are called "Job less" (Schreft and Singh, 2003 [4]). The impacts that the increase in unemployment 
can have on the country has always been studied by economists who tried to explain why, at a time when there is a growth in production, the employment rate cannot adapt, generating implications negative as poverty and social exclusion. Hence the multidimensional nature of poverty linked to the notion of social exclusion. However, opinions about the precise meaning of the term differ; in the first place, it is not always clear whether social exclusion includes poverty or vice versa or whether they are two disjointed but in any case related concepts. Indeed, social exclusion is an extremely vast phenomenon that embraces different forms of marginalization and deprivation, including poverty. It is a process that involves all individuals, with or without resources. Another aspect that characterizes the social exclusion approach is that of the accumulation of different risk factors. For Tsakloglou and Papadopoulos [5] (2002), the concept of social exclusion can be roughly described as a chronic cumulative disadvantage, understood as a combination of a plurality of social risks on the same subject. From a similar perspective, Paugam studies the processes and mechanisms of exclusion and locates them in different social spheres. These mechanisms are relational and multidimensional and include: institutional processes and mechanisms for the protection of civil and social rights and economic processes, such as the restructuring of the labor market. Moreover, these dimensions interact with each other and in more recent years, in terms of "desaffiliation" (Castel, 1995 [6]) to designate the final outcome of a process of progressive exclusion from the general social context. It is therefore a question of a dynamic nature because it implies that people are not only excluded because of their current situation, but also because of the lack of prospects for the future. Analyzing social exclusion means, therefore, understanding the process and identifying the factors that can trigger entry or exit from the condition of exclusion. Social exclusion is also a relational factor, in the sense that it implies a strong discontinuity in the relationship between the individual and the rest of society, an inadequate and incomplete social participation: being excluded, for example, because disabled, increases the risk of poverty.

The Job Less phenomenon has also been investigated in a political perspective, in which we discuss how to intervene in Italy to reduce it. In this perspective, one wonders how to use investment programs from the European Union, as in the case of Youth Guarantee. On a purely political level, in 2015, with the Renzi government, a labor reform was created, called Job act. But can the fight against unemployment and poverty be reduced to simple economic and political intervention? Starting from this question, the research aims to analyze the phenomenon of Job Less in Italy, changing the perspective and considering the jobless generation as resources that not only could produce or on which to invest, but human resources, able to tell. From the narratives and, specifically from the speeches, it is possible to listen to the "voices" of the marginalized workers, in order to understand how they experience this lack of entry into the world of work, what their real professional needs are and consequently how much they 
feel responsible of career. In this sense, the narration becomes a useful and not very invasive tool, to face a particularly delicate issue, a means through which the professional identity of the enunciator can emerge without constraints or worries. Considering the narratives as "diatexts" (Manuti \& Mininni, 2017 [7]), whose process of attribution of meaning derives from the dense network of intertwining of text and context of enunciation, quantitative-qualitative analyzes are carried out. In particular, a Sentiment Analysis (Pang \& Lee, 2008 [8]) is applied to the collected texts, which will allow us to obtain a positive, negative or neutral polarity that determines the positioning and thinking of the Italian generation without work. The qualitative methodology, based on the Critical Analysis of the Discourse, allows us to identify the existence of particular socio-epistemic rhetoric (Berlin, 1993 [9]), which, viewed from a future perspective, could represent a starting point for considering certain intervention procedures, including, for example, action on transversal skills.

\section{The Job-Less Sample}

\subsection{The Voice of the Invisible}

In spite of the legislative innovations in terms of job placement (L.68/99) and the many initiatives activated also thanks to European projects and funding, even today in Italy there are still relatively low levels of employment of disabled people. In fact, the employment rate among disabled people is equal to $21 \%$, less than half of that recorded among non-disabled people. Law 68 of 12/3/1999 establishes that, in any company with more than 50 employees, $7 \%$ of the employed must be disabled, in the companies from 36 to 50 employees two disabled workers must be hired and in the 15 to 35 employees employees, one [10] [11] [12]. Businesses can thus obtain tax benefits, reimbursements of specific expenses, support services. Not only that, but if they do not fulfill the obligation to recruit, they suffer criminal, administrative and disciplinary sanctions. It can be added that 7\% is among the highest shares in Europe [13]. Furthermore, Legislative Decree 276 of 10/9/2003 on the reform of the labor market indicates new ways for the employment of disabled people, including, inter alia, forms of assistance from third-party agencies that prepare disabled people for work and agreements between the employers' and trade union representatives and the representatives of the social cooperatives. If the laws were enough, there would be no employment problem for the disabled. The problem exists because the reality is different from what you can imagine by reading the norm. There are few entrepreneurs who prefer to pay penalties instead of hiring disabled workers. Still others take years to eliminate physical barriers that limit access to production facilities. There are those who relegate the disabled to minimal and specific activities. There is also a certain under-utilization of skills, common at times for some new recruits. We must also consider that women with disabilities are doubly disadvantaged, in fact, their employment rate is only $11 \%$ compared to men: the former have an employment rate of $11 \%$ and the latter by $29 \%$ [14] [15] 
[16]; this disadvantage also exists among non-disabled people. Some skills of people with disabilities could, in fact, emerge in contexts of life different from traditional learning contexts: an experience in itself is not significant until the subject is given a meaning that is, in part, socially built. Thus, the obligation to work insertion is often rejected (Law 68/99), too often, the politics on diversity is based only on a good idea. In this perspective it is a matter of acting in the direction of the growth of a work empowerment, whose "power" cannot be attributed to someone, but exercised by the recipient himself of the intervention. This activation is measured on the growth of choice and action skills that the person with disabilities exercises in situations, actions and interactions aimed at overcoming the disadvantage. Capabilities approach indicates that people's capacities grow if the person is put in a position to exercise them, that is, if the interested actor enhances his abilities in order to fit socially and correspond to his project of life. The hoped-for process of capacity and self-capacity, which is essential for a long-term job placement as well as, more generally, for a solid social inclusion, is currently a further major obstacle in the employment crisis. On the one hand, the job offer, especially for profit companies, has been decreasing and is increasingly oriented with the economic criteria of productivity and efficiency; on the other hand, job placement services have in turn suffered a contraction of the resources allocated to job placement and have found themselves faced with the complex task that in the past of mediation with the new needs of companies. This state of affairs makes the process of placement of the disabled in general difficult, but penalizes in a stronger way those subjects affected by those stereotypes that label them a priori as unstable, unreliable or simply "different". The prejudices towards some protected categories sometimes concern the unpredictability of behavior and a presumed lower productivity [17] [18]. These stereotypes lead a priori to a judgment of glutability, which is independent of the real will and ability of users. Furthermore, it should be noted that the disability condition often includes other disadvantaged conditions that make the subjects less "palatable" for the labor market: one of these is age, as there is a lower margin of professional retraining for all those close to the retirement age and with a very sectorial work curriculum, and any re-qualification would entail costs that the companies and they are not willing to support; another is gender, so women are disadvantaged in the labor market because of long absences in the labor market for maternity or domestic-family commitments. In this scenario, unemployed people with disabilities risk becoming invisible people, taking away their dignity and consequent lack of self-esteem. In Italy, disabled people are not guaranteed equal employment opportunities, as they are asked what a disabled person can do. In the light of a nationwide monitoring of careers and work needs of students and graduates with disabilities and Special Educational Needs it emerges, in the first analysis, that many of them could not finish the university course in progress. Most of them have chosen university studies in the field of law and humanities and at the end of the course of study $60.55 \%$ [19] is registered in the 
rankings according to Law 68/99 against the remaining 39.35\% [20] who decided not to try, result of an a priori demotivation towards the world of work. Subsequently, the survey shows that many of them managed to find a permanent job (about 66, 67\% [21]); 9.8\% [22] carry out freelance activities; 7.84\% [23] have a fixed-term contract out of a total of about 200 graduates with disabilities and Special Educational Needs (Law 53/2003). The channels that allowed us to find a job were: active and autonomous research $51.90 \%$; the targeted placement $18.99 \%$; knowledge network $17.72 \%$; University $11.39 \%$; work agency $6.33 \%$; online recruiting sites and online job agencies 3.80\%; Social 2.53\%; $1.27 \%$ associations. The data also shows that about $41.12 \%$ did not find a job consistent with the course of study carried out. The employment sectors are: Public Administration (31.37\%); Health (17.65\%) IT sector (15.69\%) and personal services (13.73\%), equal to the administrative and accounting sector (13.73\%) and finally in the field of training/education (11.76\%) [24]. Some of them participated, after graduation, in professional training courses related to activities such as: pizza chef or cook, but of the subsequent work feedback in the related sectors there are no data. In terms of social exclusion, the question of changes in work environments is very interesting, in terms of accessibility and consistency with the problems of each of them, together with the possible purchase of specific aids for disabilities or to dispense and compensate for any specific disorders of hired workers. Specifically, $82.35 \%$ [25] did not meet the will of the company or the public or private employer in favoring the accessibility of the workplace; on the other hand, the remaining $9.8 \%$ obtained modifications only following a request, regarding technological/informatic aids, structural changes of the working environment and not least minor adjustments and greater attention in an inclusive direction [26] [27]. Finally, from the direct voice of the protagonists, it emerged that the difficulties encountered in the work experience were found in the following ways:

E.g. "Farsi comprendere con il datore di lavoro. Cercare di farsi rispettare. Essere considerata una persona al pari delle altre" (difficulties due to the work environment).

Specifically, what are the needs connected with the world of work, so that we are not faced with a scenario of complete social exclusion?

\subsection{Not' a Country for Young ... But Neanche for Senior Cushioned}

Young Italians are often referred to as "choosy", literally "demanding", but in the negative sense "bamboccioni", as some statistical data show an increasing percentage of thirty/forty years do not have a job and live with their parents, or avoid looking work or not, the so-called "Not (engaged) in Education, Employment or Training” (NEET) [28] [29]. There are financial interventions deriving from the European Union which, however, do not lead to a real insertion into the world of work. These are ambitious intervention projects that, however, do not in all cases translate into effective entry into the world of work, as a high level of 
experience is required that young people do not possess. On the other hand, workers with a high level of experience [30] [31], in this panorama of flexibility could experience the discomfort of retraining, in the event of dismissal or downsizing. The consequences of these events for an old worker become a real drama, as it is difficult to adjust the work mode learned in a company context which has been part of a completely new one, which then follows different logics of the labor market. As a solution for these disadvantaged workers, the State provides financial support, such as social safety nets (NASPI). In this scenario, starting from the assumption that Italy and Europe are committed financially and legally in managing this emergency, why is the unemployment rate continuing to rise? Have you ever dealt with workers as people and not capital?

\section{Method}

Starting from the aforementioned questions, the study listened to the "voices" of human resources belonging to protected categories (disabled), young and old workers. The way in which the sample has accepted to express opinions about this delicate phenomenon, or unemployment, has been through the Internet, specifically on social networks like Facebook, in which these workers sailing in the sea of unemployment have become virtual promoters and non-virtual opposing movements of precariousness: in this case, the Net becomes a mode of mutual sharing and listening, a way to help each other. Therefore, forty-four life stories of workers belonging to the analyzed categories were collected, which are part of Facebook groups such as "Disoccupati uniti", "Diritto al lavoro per disoccupati over 40-50-60" and "Lavoro anomalo". In their speeches, which can be defined as "diatexts", because to interpret them it was necessary to refer to the current context of enunciation, that is the climate of work flexibility, work is considered as slavery. This is the case of young workers who, not having a high level of experience, talk about working experiences of internships, apprenticeships or on-call work with little flexible hours and unreasonable remuneration, as in this example:

E.g. 1: "Io I unico tipo di lavoro che sono riuscita a trovare è a chiamata e mi pagano settimanalmente in base a quanto produco (se non sbaglio si chiama lavoro a cottimo). Fortunati ad avere uno stipendio fisso a fine mese".

In the example we can see that there is the logic of the worker as a source of production and therefore gain for the company. It is interesting to note how the concept of work as slavery is in sharp contrast with the ancient conception of work that ennobles the human being. The rhetoric of slavery, moreover, is in direct correlation with the rhetoric of poverty: even in this case the work, however, to be considered as a source of income, becomes a source of unemployment because, especially in the case of workers who must retrain, over they are also underpaid to be exploited. Unlike the young workers, it emerges in older workers the impossibility of looking after the sustenance of their family, as in the following example: 
E.g. 2: "Ormai ogni lavoro è destinato a persone sotto i 29 anni, in alcuni casi 35, poi STOP! Sei out, fuori, non esistiti! E come campiamo, cresciamo i nostri figli e andiamo avant? Oltre al lavoro non avremo mai nemmeno la pensione... sempre che non muoriamo di fame o crepacuore prima...”.

Work in Italy is also seen as a devaluation of professionalism, especially for young graduates who find themselves doing jobs that are not consistent with the object of their training, which are consequently paid badly, as in the following example:

E.g. 3: "Sono laureato in lettere 110 e lode. Ho lavorato per anni come freelance ma da quando sono nato non ho mai trovato un lavoro in regola, solo lavori pagati con ritenuta di acconto, come gli attuali. Lavoro come rilevatore statistico per 240 euro ogni 2 mesi e in una università privata per 240 ogni 4 mesi. Sto mangiando pasta a pranzo e a cena per andare avanti, Non si trova nessun lavoro se non sei raccomandato. Ho tentato tantissimi concorsi inutilmente. Ora non ci provo neanche piü'.

Another interesting rhetoric concerns the binomial between disability and work. From the testimony, it can be seen that, although there is greater legal protection for workers belonging to protected categories, work is no longer seen as an opportunity, but as a source of discrimination, as in the following example:

E.g. 4: "Penso che il problema della disoccupazione giovanile sia un problema veramente serio e tanti ricercatori giovani stanno fuggendo all estero proprio perchè in Italia non ci sono prospettive serie di lavoro. Però (senza togliere nulla ai giovani in quanto tutti abbiamo diritto a un lavoro) la situazione di noi over 40-50-60 e disabili è ancora più grave perchè per lo stato siamo invisibili, discriminati per etâ dalle aziende per Pinserimento lavorativo e di conseguenza respinti dalle aziende, infine $i$ disabili non lavorano. Questo gruppo Pho creato proprio perche io stessa disabile invalida civile alp $80 \%$ ho perso il lavoro nel 2006 e non sono stata mai reinserita in un altro lavoro ne con la legge per i lavoratori in mobilitâ a cui ero iscritta, né Tantomeno con la legge 68/99. A cui sono a tut' oggi iscritta quindi per me si tratta di una doppia discriminazione. Sto lottando da anni contro questa discriminazione ... presto entrero a far parte di una associazione onlus per un progetto di lavoro che devo cercare di attuare qui a Roma. Ci provo e spero di riuscirci per aiutare tutti quelli come me che sono espulsi dal mondo del lavoro".

In this specific case we are talking about "double discrimination", because to tell its story is a woman with disability who needs to retrain who, however, has never been re-inserted.

\section{Conclusion and Future Prospects}

The research has allowed us to reflect on the current working situation in a climate of flexibility following globalization, which has generated social inequality and an increase in the unemployment rate, especially in marginal areas of Europe, as happens in Italy, where interventions are aimed at legislative or financial 
attempts, but instead it would be important to deal with the person as a worker. From listening to narratives on the net, this great need has emerged, it is made clear that unemployment is not only an economic problem, but the impossibility of re-acting. On the basis of the rhetoric that emerged and therefore the consideration of work as slavery, poverty, professional devaluation and discrimination, it becomes necessary to put in place strategies to tackle unemployment that aim at listening, as it becomes important to consider all those non-visible variables of a worker, such as career guidelines, motivations, attitudes... and improve a social-relationship dialogue between worker, company and political party. A practical example of intervention could be the introduction of good practice in the selections to explain to the unsuitable candidates the reason for the refusal. Another need of current workers is to be strengthened, so interventions should be planned aimed at the acquisition of transversal skills, i.e. all those skills that can be used in any context to face professional flexibility. Taking care of people as workers and following them on a career management path means increasing the possibility of employment and, consequently, reappropriation of the foundations of the Constitution, according to which Italy is a republic founded on work.

\section{Conflicts of Interest}

The authors declare no conflicts of interest regarding the publication of this paper.

\section{References}

[1] Briscoe, J.P., Hall, D.T. and DeMuth, R.L.F. (2006) Protean and Boundaryless Careers: An Empirical Exploration. Journal of Vocational Behavior, 69, 30-47. https://doi.org/10.1016/j.jvb.2005.09.003

[2] Arthur, M.B. (1994) The Boundaryless Career: A New Perspective for Organizational Inquiry. Journal of Organizational Behavior, 15, 295-306. https://doi.org/10.1002/job.4030150402

[3] Arthur, M.B. and Rousseau, D.M., Eds. (1996) The Boundaryless Career: A New Employment Principle for a New Organizational Era. Oxford University Press, New York.

[4] Schreft, S.L. and Singh, A. (2003) A Closer Look at Jobless Recoveries. Economic Review, Federal Reserve Bank of Kansas City.

[5] Tsakloglou, P. and Papadopoulos, F. (2002) Aggregate Level and Determining Factors of Social Exclusion in Twelve European Countries. Journal of European Social Policy, 12, 211-225. https://doi.org/10.1177/0952872002012003394

[6] Castel, R. (1995) Les métamorphoses de la question sociale. Fayard, Paris.

[7] Manuti, A. and Mininni, G. (2017) A Rose Is More than a Rose ... The Diatextual Constitution of Subjects and Objects. De Gruyter Mouton, 37, 243-263.

[8] Pang, B. and Lee, L. (2008) Opinion Mining and Sentiment Analysis. Foundations and Trends in Information Retrieval, 2, 1-135. https://doi.org/10.1561/1500000011

[9] Berlin, J. (1993) Poststructuralism, Semiotics, and Social-Epistemic Rhetoric: Converging Agendas. In: Enos, T. and Brown, S., Eds., Defining the New Rhetorics, 
Sage, Newbury Park, CA, 137-176.

[10] Figueiredo, J.B. and de Haan, A. (1998) Social Exclusion. An ILO Perspective. ILO, Geneva.

[11] ILO (2004) Statistics on the Employment Situation of People with Disabilities. A Compendium of National Methodologies, ILO Policy Integration Department Working Paper N. 40, in Collaboration with the InFocus Programme on Skills, Knowledge and Employability, ILO, Geneva.

[12] ILO (2007) The Employment Situation of People with Disabilities: Towards Improved Statistical Information. ILO Bureau of Statistics in Collaboration with the ILO Skills and Employability Department, Geneva.

[13] ILO (2008) ILO Declaration on Social Justice for a Fair Globalization. ILO, Geneva.

[14] ISTAT (2009) La disabilità in Italia. Il quadro della statistica ufficiale, Argomenti n. 37, Istat, Roma.

[15] ISTAT (2009) L'indagine europea sui redditi e le condizioni di vita delle famiglie (eu-silc). 2008, Metodi e Norme n. 37.

https://www.istat.it/en/files/2014/06/met_norme0837_indagine_europea_sui_reddit i_Eu-Silc.pdf

[16] ISTAT (2011) L'integrazione degli alunni con disabilità nelle scuole primarie e secondarie di I grado, statali e non statali.

https://www.istat.it/it/files/2018/03/alunni-con-disabilit\%C3\%A0-as2016-2017.pdf

[17] Messel, E. (1997) Employment Strategies for Women with Disabilities. The International Leadership Forum for Women with Disabilities, Washington DC, 15-20 June 1997, 200.

[18] Metts, R.L. (2000) Disability Issues, Trends and Recommendations for the World Bank. World Bank Social Discussion Paper No. 0007, Social Protection Unit, Human Development Network, World Bank, Washington DC.

[19] OECD (2003) Transforming Disability into Ability. Policies to Promote Work and Income Security for Disabled People. OECD, Paris.

[20] OECD (2004) Vocational Rehabilitation of Employment of People with Disabilities. OECD, Paris.

[21] OECD (2006) Sickness, Disability and Work. Breaking the Barriers: Norway, Poland and Switzerland. Volume I, OECD, Paris.

[22] OECD (2009) Sickness, Disability and Work. Addressing Policy Challenges in OECD Countries. OECD High-Level Forum, Stockholm.

[23] OECD (2010) Education at a Glance. OECD Indicators, OECD, Paris.

[24] ISTAT (2008) L’assistenza residenziale e socio-assistenziale in Italia. https://www.istat.it/it/archivio/9122

[25] O’Really, A. (2007) The Right to Decent Work of Persons with Disabilities. International Labour Office, Geneva.

[26] Pagan, R. (2009) Self-Employment among People with Disabilities: Evidence for Europe. Disability and Society, 24, 217-229.

[27] Schur, L., Kruse, D., Blasi, J. and Blanck, P. (2009) Is Disability Disabling in all Workplaces? Workplace Disparities and Corporate Culture. Industrial Relations, 48, 381-410. https://doi.org/10.1111/j.1468-232X.2009.00565.X

[28] Carr, S.C., Inkson, K. and Thorn, K. (2005) From Global Careers to Talent Flow: Reinterpreting “Brain Drain”. Journal of World Business, 40, 386-398. https://doi.org/10.1016/j.jwb.2005.08.006 
[29] Docquier, F. and Rapoport, H. (2012) Quantifying the Impact of Highly Skilled Emigration on Developing Countries. In: Boeri, T., Brücker, H., Docquier, F. and Rapoport, H., Eds., Brain Drain and Brain Gain-The Global Competition to Attract High-Skilled Migrants, Oxford University Press, Oxford, 336.

[30] Incorvaia, A. and Rimassa, A. (2006) Generazione mille euro. Rizzoli, Milano.

[31] Waterman, R.H., Waterman, J.A. and Collard, B.A. (1994) Toward a Career Resilient Workforce. Harvard Business Review, 74, 86-95. 